\title{
Evidence of mid- to late-Holocene explosive rhyolitic eruptions from Chaitén Volcano, Chile
}

\author{
Sebastian F.L. Watt ${ }^{1,2}$, David M. Pyle ${ }^{1}$, Tamsin A. Mather ${ }^{1}$ \\ ${ }^{I}$ Department of Earth Sciences, University of Oxford, South Parks Road, Oxford OXI 3AN, U.K. \\ sebastian.watt@noc.soton.ac.uk; david.pyle@earth.ox.ac.uk; tamsin.mather@earth.ox.ac.uk \\ ${ }^{2}$ National Oceanography Centre, Southampton, University of Southampton Waterfront Campus, European Way, Southampton SO14 \\ $3 Z H, U . K$.
}

\begin{abstract}
The 2008 eruption of Chaiten Volcano was widely cited as the first activity at the volcano for over 9000 years. However, we have identified evidence from proximal pyroclastic deposits for three additional explosive eruptions of Chaitén within the past 5000 years. Chaitén has therefore produced at least five explosive eruptions in the Holocene, making it among the most active volcanoes, in terms of explosive output, in the southern part of the Andean Southern Volcanic Zone. All of the five identified Holocene explosive eruptions produced homogeneous high-silica rhyolite, with near identical compositions. Based on our pyroclastic sequence, we suggest that the largest-volume Holocene eruption of Chaitén occurred at $\sim 4.95 \mathrm{ka}$, and we correlate this with the Mic2 deposit, which was previously thought to originate from the nearby Michinmahuida Volcano.
\end{abstract}

Keywords: Chaitén Volcano, Andean southern volcanic zone, Holocene tephra stratigraphy, Rhyolite, Explosive volcanism.

RESUMEN. Evidencia de erupciones riolíticas del Holoceno medio a tardío del volcán Chaitén, Chile. La erupción del volcán Chaitén en el año 2008 ha sido mencionada ampliamente como la primera actividad de este en los últimos 9 mil años. Sin embargo, en este trabajo se muestra evidencia de depósitos piroclásticos proximales derivados de tres erupciones explosivas adicionales del Chaitén durante los últimos 5 mil años. Por lo tanto, este volcán ha producido al menos cinco erupciones explosivas en el transcurso del Holoceno, lo que sugiere que corresponde a uno de los volcanes más activos, en términos de erupciones explosivas, del extremo meridional de la zona volcánica sur de los Andes. Las cinco erupciones holocenas se caracterizan por la emisión de productos de composición similar: riolitas de alto contenido de sílice. De acuerdo a la secuencia piroclástica analizada, se sugiere que la mayor erupción holocena del volcán Chaitén ocurrió ca. 4,95 ka. Esta erupción, asociada al depósito piroclástico Mic2, se interpretó previamente como derivada del volcán Michinmahuida. 


\section{Introduction}

Little was known about the Holocene eruption history of Chaitén Volcano before its most recent eruption in 2008. Before 2008, Chaitén comprised a rhyolitic lava dome nested within a $2.5 \mathrm{~km}$ wide caldera. The 2008 eruption led to the destruction of the old dome and the growth of a new dome within the caldera (Pallister et al., 2013, this volume).

Chaitén is situated in a remote forested region of southern Chile $\left(42.8^{\circ} \mathrm{S}, 72.6^{\circ} \mathrm{W}\right)$, in the southern part of the Andean southern volcanic zone (SVZ; Stern, 2004). Tephrochronological investigations in this region have focussed primarily on deposits from the largest explosive eruptions (Naranjo and Stern, 2004; Watt et al., 2011a). Previous work by Naranjo and Stern (2004) recognised a pyroclastic surge and rhyolitic tephra fall deposit from Chaitén, named Cha1, dispersed northwards and now dated at $\sim 9.75 \mathrm{ka}$ (based on calibrated radiocarbon ages; Watt et al., 2011a). Because of an absence of recognised and dated eruption products younger than Cha1, it has been widely cited that the 2008 eruption represented the first activity at Chaitén for over 9000 years (e.g., Gudmundsson, 2009; Stewart et al., 2009; Wang et al., 2009), which would imply a notably long period of quiescence.

An additional rhyolitic tephra deposit, named Mic2, was identified and dated by Naranjo and Stern (2004) $\sim 100 \mathrm{~km}$ east of Chaitén, in Argentina. Mic2 was attributed to Michinmahuida, a large stratovolcano $20 \mathrm{~km}$ east of Chaitén, since this was the closest volcano in the upwind direction. However, no proximal equivalent of Mic2 has been identified, and the defined distribution of Mic2 cannot differentiate between Chaitén and Michinmahuida as source volcanoes (Fig. 1). Furthermore, the rhyolitic composition of Mic2 differs from an older andesitic tephra (Mic1) and the basaltic to andesitic lavas at Michinmahuida (Kilian and López-Escobar, 1991; López-Escobar et al., 1993; Naranjo and Stern, 2004), but is highly similar to the known eruption products from Chaitén (Naranjo and Stern, 2004; Castro and Dingwell, 2009; Watt et al., 2009). If sourced from Chaitén, the age of Mic2 ( 4.2 calibrated ka BP; Naranjo and Stern, 2004) suggests that Chaitén has erupted much more recently than has been previously recognised.

Here, we report on a proximal sequence of pyroclastic deposits, which provides potential evidence for mid- to late-Holocene eruptions at Chaitén and the opportunity for correlation with previously identified distal tephra deposits such as Mic2.

\section{Pyroclastic sequence description}

A roadside soil sequence (site F-02, Fig. 1; $41.8103^{\circ} \mathrm{S}, 72.6764^{\circ} \mathrm{W}$ ) was newly exposed $2.5 \mathrm{~km}$ NW of the Chaitén lava dome, following erosion during the early stages of the May 2008 eruption. Site F-02 lies near the southern margin of a zone of dead vegetation NW of Chaitén Volcano, at a point where steep slopes leading down from the caldera rim meet a wide valley floor. In May 2008, extensive flooding and secondary lahars resulted in ash re-deposition and vegetation death in this valley and across a wide proximal region (Lara, 2009; Alfano et al., 2011). In the vicinity of site F-02, the road appears to have acted as a flood conduit, leading to extensive roadside erosion and the exposure of a fresh stratigraphic sequence.

At the base of the F-02 exposure (Fig. 2) is a multi-layered deposit, $>1.5 \mathrm{~m}$ thick in places, which we name Cha2. The deepest exposed part of Cha2 is a coarse debris flow deposit, with a poorly-sorted matrix of mud and sand supporting angular lithic blocks up to $40 \mathrm{~cm}$ diameter, and also containing several large pieces of wood (with no evidence of charring), rare pumice and grey obsidian chips. Lithics are aphanitic grey or red rhyolite, apparently derived from the Chaitén dome or surrounding caldera walls. The mix of aphanitic rhyolite, obsidian and pale pumice, all of which are aphyric, is similar in appearance to deposits left in stream gullies near site F-02 during the 2008 eruption, and to a lithic-rich lapilli unit near the base of the 2008 fall deposit ( $\beta$-unit of Alfano et al., 2011).

The irregular top surface of the Cha-2 debrisflow deposit is overlain by a sequence of pyroclastic flow, surge and fall deposits, forming the upper part of the Cha2 deposit (Fig. 2). Directly above the debris flow deposit lies a well-indurated, very poorly sorted lapilli deposit. This unit is dominated by pale yellow pumice, with minor lithics and obsidian, and we interpret it as a pyroclastic flow deposit. It has a locally variable thickness of 20-60 cm, with a matrix of coarse ash supporting rare sub-rounded lava clasts with a maximum diameter of $10 \mathrm{~cm}$. The deposit is generally structureless except for a poorly preserved upper part, which is normally graded with faint parallel laminations. Draping the top of the 


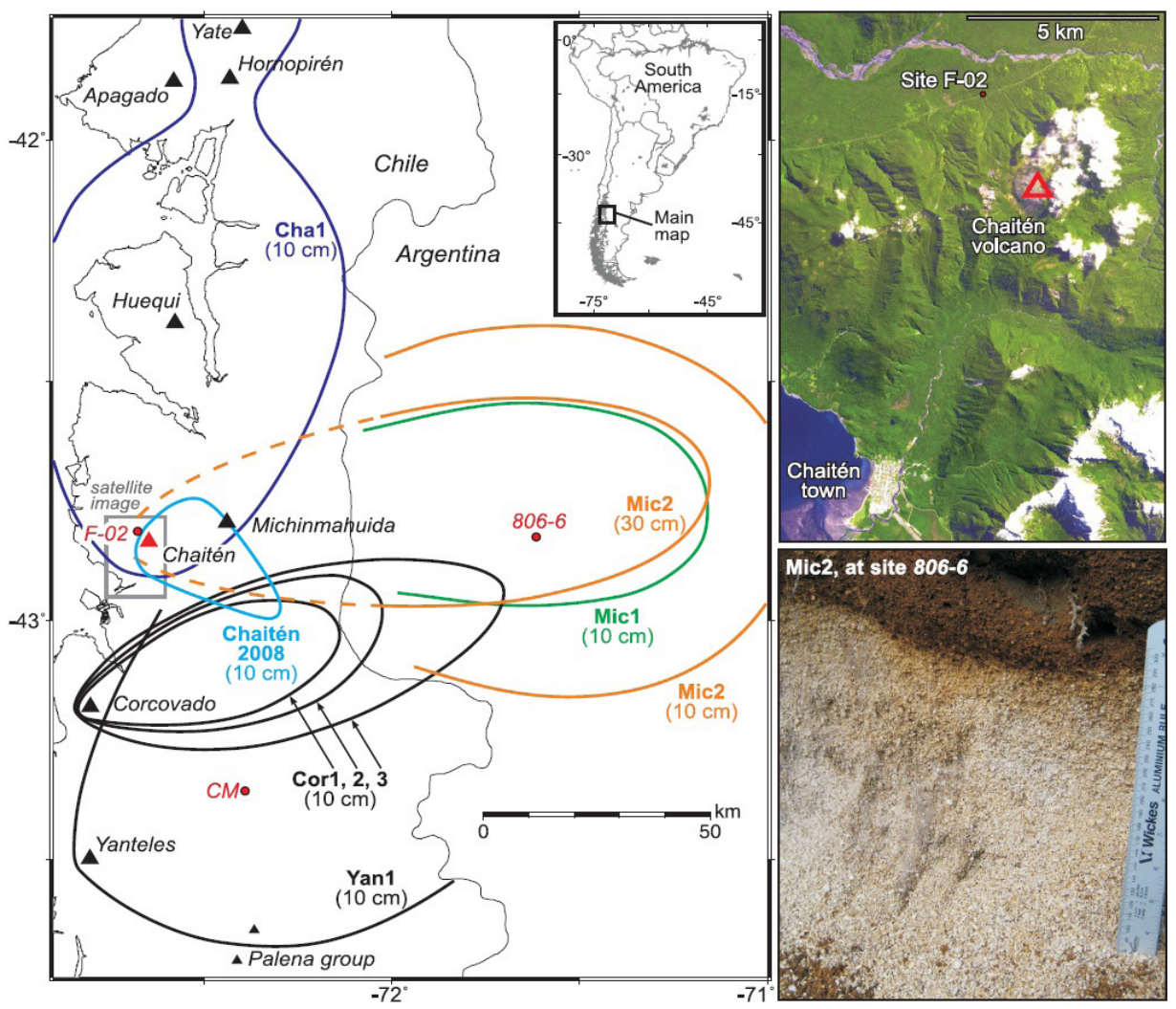

FIG. 1. A segment of the Andean southern volcanic zone (SVZ). Isopachs have been drawn for known Holocene tephra deposits, at $10 \mathrm{~cm}$ thickness for fall deposits from Chaitén, Michinmahuida, Corcovado and Yanteles (Naranjo and Stern, 2004; Alfano et al., 2011; Watt et al., 2011a; and authors' new field observations). A $30 \mathrm{~cm}$ isopach is also shown for Mic2. The ASTER image (NASA) on the top right, acquired before the 2008 Chaitén eruption (23/10/2005), shows the location of site F-02. The photograph on the bottom right shows the 50 -cm-thick Mic2 pumice deposit at site $806-6$ (main map; $42.8216^{\circ} \mathrm{S}, 71.6177^{\circ} \mathrm{W}$ ).

pyroclastic flow deposit is a pale yellow fine ash fall deposit ( $2 \mathrm{~cm}$ thick) with parallel laminations, and then two deposits interpreted as pyroclastic surge deposits, separated by another fine ash fall deposit ( $2 \mathrm{~cm}$ thick). The surge deposits display low-angle unidirectional cross stratification, with well-sorted laminae of coarse ash to fine lapilli. They are dominated by yellow pumice grains, with rarer lithic and obsidian fragments and rare coarser pumices (2-4mm). The upper surge deposit is slightly coarser and more abundant in angular lithic clasts (red or grey lava, up to $6 \mathrm{~mm}$ across). The surge deposits have a slightly variable local thickness, of $\sim 10 \mathrm{~cm}$, and are overlain by a 4 -cm-thick structureless lapilli deposit, with weathered yellow pumices $(5 \mathrm{~mm}$ diameter), obsidian chips, and abundant angular lava fragments (5-10 mm diameter), which marks the top of Cha2.
We interpret Cha2 as a deposit associated with a single large eruption. An early debris flow may have been associated with the destruction of an old dome and vent clearing during the initial stages of an explosive eruption. Abundant wood within the debris-flow deposit suggests that this event cleared and entrained vegetation from the slopes of the volcano. The presence of rare pumice clasts suggests that this debris flow occurred during the initial stage of an eruption that produced the overlying pyroclastic deposits. No vegetation fragments were found in the pyroclastic deposits that form the upper part of Cha2. This upper part is rich in juvenile material, and suggests a multi-stage explosive eruption producing pumice-rich pyroclastic flows with intermittent ash fall. The lack of coarse-grained fall deposits potentially indicates that this site lay in an upwind position, as was the case during the 2008 eruption (Alfano et al., 2011). 
Overlying Cha2 is a sequence of three wellsorted pumice fall deposits (here named F2C, Cha3 and Cha4; Fig. 2), each a few centimetres thick, separated by organic-rich soils. The oldest deposit (F2C) is notably more weathered, yellow-orange in color, and the finest grained, with a maximum pumice size of $5 \mathrm{~mm}$. The middle deposit (Cha3) is the coarsest, with yellow-grey, low-density aphyric grains with a maximum pumice size of $10 \mathrm{~mm}$, and minor proportions of angular grey lava fragments. Cha4 has an uneven basal surface and is similar in appearance to Cha3. It contains yellow-grey to white pumices (maximum pumice size $10 \mathrm{~mm}$ ) and is moderately rich in angular grey lava fragments (2-4 mm). Almost at the top of the sequence (i.e., mantled by the Chaitén 2008 ash fall) is a soil rich in coarse angular lithic clasts, up to several centimetres across, which is likely to reflect local slope failures (Fig. 2). At site F-02, the Chaitén 2008 deposit is a coarse grey ash, with faint millimetre-scale laminations, $3.5 \mathrm{~cm}$ in thickness (Alfano et al., 2011).

To summarise, four separate pyroclastic deposits are present in the F-02 sequence (Fig. 2), with the basal unit apparently representing a large, multistage event, the base of which is not exposed, and the three subsequent deposits representing relatively smaller explosive eruptions.

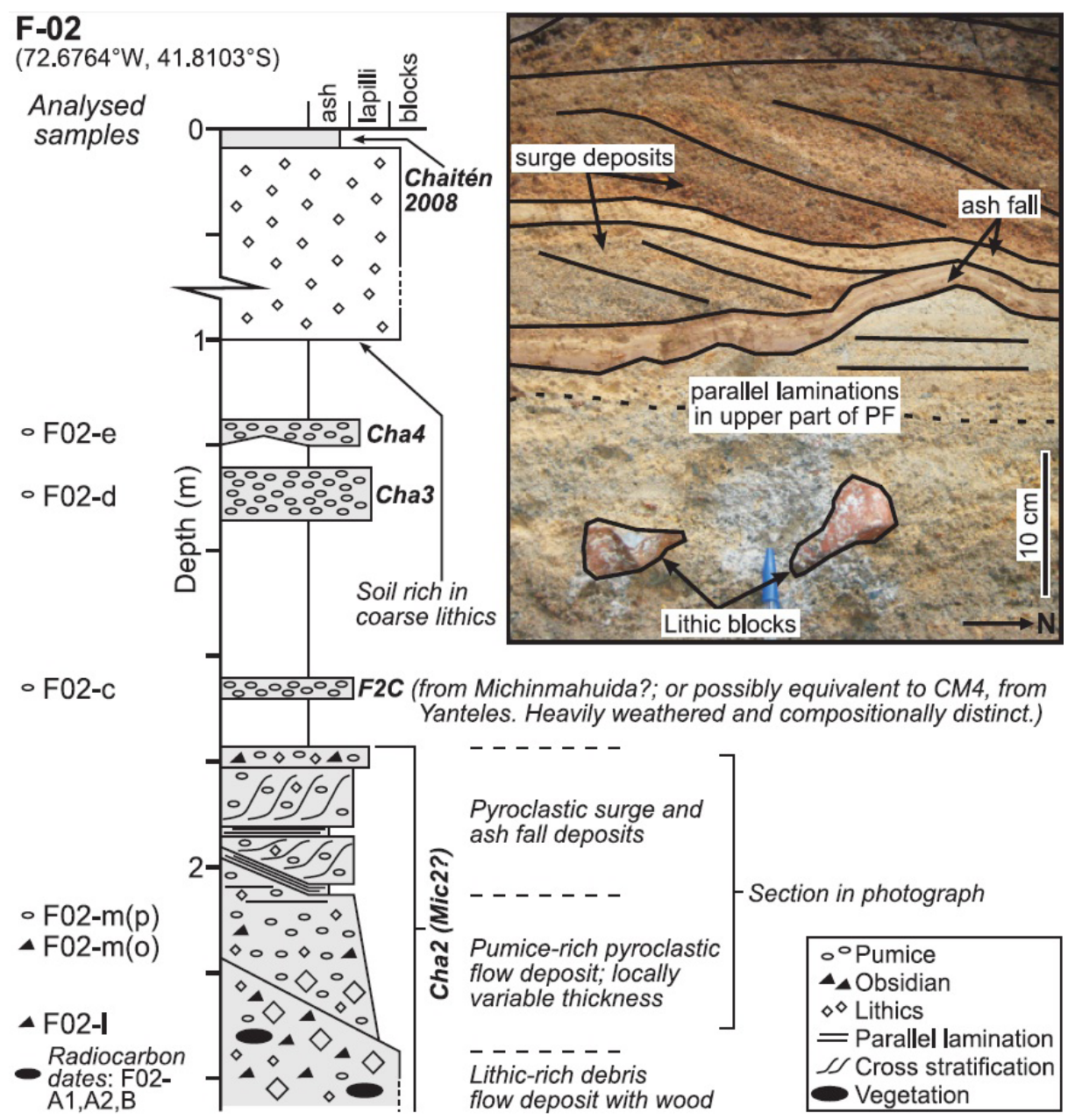

FIG. 2. Stratigraphic section at site F-02 (location in Fig. 1). Names of samples are on the left. Eruption deposits are shaded in grey, with unit names given in bold-italic font. The photograph shows the Cha2 deposit, corresponding to the indicated part of the stratigraphic column. 


\section{Eruption ages and regional tephra stratigraphy}

Three radiocarbon dates have been obtained from two pieces of wood (branches $\sim 10 \mathrm{~cm}$ in diameter) in the debris flow deposit at the base of Cha2 (Table 1; Fig. 2). The samples were analysed by Beta Analytic Inc. (Miami, Florida) and prepared in a standard fashion: samples were crushed and dispersed in deionized water, washed sequentially in hot $\mathrm{HCl}$ followed by $\mathrm{NaOH}$, and rinsed in acid to neutralize the solution before drying. Treated wood samples were then bathed in sodium hypochlorite $\left(\mathrm{NaClO}_{2}\right)$ under controlled conditions $\left(\mathrm{pH} 3\right.$, at $\left.70^{\circ} \mathrm{C}\right)$ to remove all components except wood cellulose. Samples were analysed for radiocarbon by accelerator mass spectrometry (AMS), and corrected for fractionation assuming a $\delta^{13} \mathrm{C}$ of $-25 \%$. All dates reported in this paper are given in calibrated years BP, and have been calibrated using OxCal 4.1 (Bronk Ramsey, 2009) and the Southern Hemisphere calibration curve (McCormac et al., 2004).

The three radiocarbon dates in Table 1 are consistent. By combining the dates using OxCal 4.1 (Bronk Ramsey, 2009) we obtain an age of $4.95 \pm 0.1 \mathrm{ka}$ for Cha2 (calibrated age range of 5040-4857 BP at the $95.4 \%$ highest probability density). Thus, the four eruption deposits identified in F-02 represent eruptions in the past $5 \mathrm{kyr}$. This is younger than any previously identified activity at Chaitén (Cha1 is dated at $\sim 9.75 \mathrm{ka}$; Watt et al., 2011a). Of the documented major regional tephra deposits from nearby volcanoes (Naranjo and Stern, 2004), only Mic2, at $4.2 \mathrm{ka}$, overlaps in age with the F-02 pyroclastic sequence. Mic1 ( 7.3 ka) and four regionally-distributed tephra deposits from Yanteles and Corcovado Volcanoes (Fig. 1), south of Chaitén, are all older than 7 ka (Naranjo and Stern, 2004).

We have estimated the tephra deposit volumes of Mic 1 and Mic2 by using the thickness measurements in Naranjo and Stern (2004) and some of our own observations to construct a single isopach for Mic1 and multiple isopachs for Mic2. By using the isopach areas, and following the methods outlined by Pyle $(1989,1999)$, we obtain a volume estimate for Mic1 of $1.5 \mathrm{~km}^{3}$ and for Mic2 of $4.7 \mathrm{~km}^{3}$. We emphasize that these are approximate values, based on a small number of distal tephra deposit measurements. However, the volume for Mic2 is likely to be a minimum, because we enclosed the isopachs around Michinmahuida, which was the source suggested for this deposit by Naranjo and Stern (2004). If, as we suggest below, the Mic2 deposit originated from Chaitén (Fig. 1), then the isopach areas and corresponding volume estimate would be slightly larger. Our estimates compare with a volume for the Cha1 tephra of $3.5 \mathrm{~km}^{3}$ (Watt et al., 2009). These volumes are all significantly larger than the Chaitén 2008 eruption, which had a total tephra volume of $\leq 0.5-1.0 \mathrm{~km}^{3}$ (Watt et al., 2009; Alfano et al., 2011), and suggest that Mic2 was the largest of the known eruptions from Chaitén or Michinmahuida. The difference in magnitude between Mic2 and the 2008 Chaitén eruption is well illustrated at site 806-6, $85 \mathrm{~km}$ east of Chaitén Volcano near Lake Futalaufquén, in Argentina (Fig. 1). Here, Mic2 has a thickness of $50 \mathrm{~cm}$, and contains pumice lapilli with a maximum diameter of $8 \mathrm{~mm}$. In spite of a similar transport direction, the Chaitén 2008 deposit at the same site has a $3 \mathrm{~mm}$ thickness and is a fine grey ash, with a discontinuous coarse ash layer at the top surface (Watt et al., 2009).

TABLE 1. RADIOCARBON DATES FOR THE CHA2 DEPOSIT.

\begin{tabular}{|c|c|c|c|c|c|}
\hline Samplea & Lab number & Sample type & $\delta^{13} C_{\mathrm{PDB}}$ & $\begin{array}{l}\text { Conventional age } \\
\text { (error), }{ }^{14} \mathrm{C} \text { yr BP }\end{array}$ & $\begin{array}{c}\text { Calibrated age }{ }^{\mathrm{b}} \text {, } \\
\text { cal. yr BP }\end{array}$ \\
\hline F02-B & Beta-297270 & Wood & $-21.5 \%$ & $4390(40)$ & $5039-4834$ \\
\hline F02-A2 & Beta-297269 & Wood (outside of branch) & $-25.2 \%$ & $4450(40)$ & $5272-4852$ \\
\hline F02-A1 & Beta-297268 & Wood (centre of branch) & $-21.2 \%$ & $4450(40)$ & $5272-4852$ \\
\hline
\end{tabular}

${ }^{a}$ All samples were taken from within the basal debris flow unit of Cha2 (Fig. 2). Analysis by AMS dating at Beta Analytic Inc., Miami, Florida.

${ }^{\mathrm{b}}$ Calibrated by OxCal4.1 (Bronk Ramsey, 2009) and the Southern Hemisphere calibration curve (McCormac et al., 2004). 


\section{Chemical analysis}

Chaitén is notable for having erupted high-silica rhyolites apparently exclusively. Such compositions are rare in this part of the SVZ. The rhyolite erupted in 2008 was nearly aphyric (Castro and Dingwell, 2009), and Cha1 and Mic2 comprise similarly homogeneous, aphyric white pumice deposits (Naranjo and Stern, 2004; Watt et al., 2011a). We have compared glass compositions of six F-02 samples (Fig. 2) with those of samples from Cha1 and Chaitén 2008 (Watt et al., 2009, 2011a) and also with a sample of Mic2 pumice from site 806-6 (Fig. 1).

Glass major element compositions were measured on multiple grains by electron microprobe (JEOL8600 at the University of Oxford, U.K.) on polished, resin mounted samples from F-02 (four samples of pumice grains [F02-m(p), F02-c, F02-d, F02-e], two of obsidian chips [F02-I, F02-m(o)]), Cha1, Mic2 and Chaitén 2008. Analyses used a 5-micron spot size with a beam current of $4 \mathrm{nA}$ at $15 \mathrm{kV}$. For Chaitén 2008, we used samples of proximal pumice and obsidian lapilli and coarse ash (Alfano et al., 2011). For Cha1, we analysed a proximal pumice block and several distal pumice grains (Watt et al., 2011a). We have excluded analyses of lithic grains here, because they had a mixed appearance in several deposits and potentially sample dome rock from older eruptions, rather than juvenile material.

\section{Analytical results}

There is a clear compositional outlier among the F-02 units (Fig. 3). This outlier is deposit F2C (encircled in Fig. 3), and its wide compositional scatter is in contrast to all the other F-02 units, which have extremely similar glass major-element compositions that also overlap with bulk compositional measurements of samples from Cha1 and Mic2 (Fig. 3). F2C is the most weathered of the three upper fall deposits at site F-02 (Fig. 2), and has the finest grain-size. Its glass composition classifies it as a dacite, but there is a fractionation-related scatter in the analyses. Such scatter is not unusual among the major element glass composition of separate grains from individual tephra deposits (e.g, Haberle and Lumley, 1998). Perhaps more unusual is the near-identical composition of all the remaining F-02 units and of Chal, Chaitén 2008, and Mic2, which is consistent for all major element oxides.

All known eruptive products from Chaitén are rhyolitic, and the dacitic composition of F2C (Fig. 3) therefore suggests a different source volcano. This is consistent with the relatively finer grain size of the fall deposit at site F-02. Our radiocarbon dates show that $\mathrm{F} 2 \mathrm{C}$ is younger than $5 \mathrm{ka}$ (Fig. 1), and cannot therefore be any of the recognised older units from Corcovado, Michinmahuida or Yanteles (Naranjo and Stern, 2004). F2C may represent an unidentified
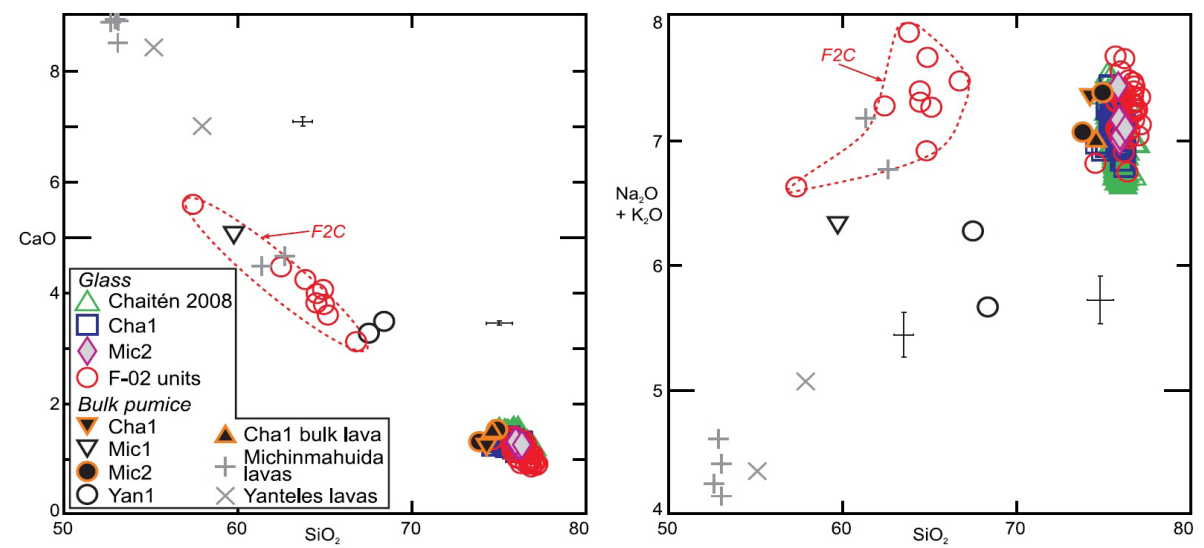

FIG. 3. Silica versus alkali content and $\mathrm{CaO}$ for all analysed samples. F2C is clearly distinct, and may represent an unidentified eruption from Michinmahuida. All remaining units from site F-02 are high-silica rhyolites of extremely similar composition. Representative $\pm 1 \sigma$ instrumental error bars are shown, based on the analytical variation of glass secondary standards used to check instrument calibration. Bulk pumice compositions are from Naranjo and Stern (2004) and bulk lava compositions from Kilian and López-Escobar (1991) and López-Escobar et al. (1993). These have all been normalized to 100\% anhydrous values for direct comparison with the glass compositions. 
eruption of Michinmahuida. A possible alternative is that F2C correlates with an ash deposit identified by Heusser et al. (1992), named CM4 and attributed to Yanteles Volcano. CM4 has a poorly constrained age $(4.5 \pm 2 \mathrm{ka})$, and forms a triple layered yellow-brown ash to lapilli unit at Cuesta Moraga (site CM, Fig. 1), $40 \mathrm{~km}$ ENE of Yanteles (Fig. 1). The triple layer suggests a moderately large eruption comprising multiple phases, and it is plausible that a northward trajectory could at some stage have produced a deposit overlapping with site F-02. Unfortunately there is no chemical data available for $\mathrm{CM} 4$, but the age, stratified appearance and distribution are potentially consistent with F2C. The composition of F2C is relatively similar to early Holocene tephras from both Michinmahuida and Yanteles (Mic1 and Yan1 in Fig. 3; Naranjo and Stern, 2004), although it is significantly more potassic than either of these. The high potassium content of $\mathrm{F} 2 \mathrm{C}$ is, however, similar to some Michinmahuida lavas (Fig. 3), but does not overlap with any known Yanteles lavas. We suggest that Michinmahuida is therefore the most likely source of $\mathrm{F} 2 \mathrm{C}$, but without further compositional data we cannot discount CM4 as a potential equivalent deposit.

The remaining F-02 units, as well as Cha1, Mic2 and the Chaitén 2008 deposit, have very similar glass compositions (Fig. 3; Table 2), forming a tight compositional cluster and suggesting a homo- geneous stock of magma (cf. Castro and Dingwell, 2009; Watt et al., 2009). Based on their rhyolitic composition, we suggest that all of these deposits, including Mic2, originate from Chaitén. The Mic2 eruption has a calibrated age of $4.2 \pm 0.2 \mathrm{ka}$ (using the single radiocarbon date of Naranjo and Stern (2004)), which overlaps with the F-02 sequence of deposits. This raises the question as to which of the units in F-02, if any, corresponds to Mic2.

The upper two rhyolites in F-02 (Cha3 and Cha4) are lapilli fall deposits, while the lowest (Cha2) forms a thicker sequence of flow deposits, dated here at $4.95 \pm 0.1 \mathrm{ka}$. Cha3 and Cha4 lie in the upper half of the F-02 sequence, and are therefore likely to be too young to correlate with Mic2 (although their age is poorly constrained). They have not been identified at any other sites (i.e., along road cuts to the east, where Mic2 is preserved), and our constraints on eruption parameters are therefore poor. We tentatively suggest that they represent eruptions much smaller than Cha2 and were deposited from plumes with a more northerly trajectory, similar to Cha1 (Fig. 1).

Mic2 is the largest-volume tephra deposit known in a wide segment of the SVZ between Macá $\left(45.1^{\circ} \mathrm{S}\right.$, $\left.73.2^{\circ} \mathrm{W}\right)$ and Quetrupillán $\left(39.5^{\circ} \mathrm{S}, 71.7^{\circ} \mathrm{W}\right)$ Volcanoes. This highly explosive eruption, if sourced from Chaitén, would be expected to form a thick proximal deposit. The pyroclastic density current deposits of Cha2 (at site F-02) were potentially formed by column

TABLE 2. AVERAGE GLASS COMPOSITIONS (NORMALIZED 100\% ANHYDROUS) MEASURED BY ELECTRON MICROPROBE FOR IDENTIFIED CHAITÉN ERUPTION DEPOSITS.

\begin{tabular}{|c|c|c|c|c|c|c|c|c|c|c|c|c|c|c|}
\hline Unit: & \multicolumn{2}{|c|}{ Cha1 } & \multicolumn{2}{|c|}{ Cha2 } & \multicolumn{2}{|c|}{ Cha2 } & \multicolumn{2}{|c|}{ Mic2 } & \multicolumn{2}{|c|}{ Cha3 } & \multicolumn{2}{|c|}{ Cha4 } & \multicolumn{2}{|c|}{ Chaitén 2008} \\
\hline Samples: & \multicolumn{2}{|c|}{$\begin{array}{c}\text { Proximal and } \\
\text { distal }\end{array}$} & \multicolumn{2}{|c|}{$\begin{array}{c}\text { F2-M/L } \\
\text { (obsidian) }\end{array}$} & \multicolumn{2}{|c|}{$\begin{array}{c}\text { F2-M } \\
\text { (pumice) }\end{array}$} & \multicolumn{2}{|c|}{$806-6 c$} & \multicolumn{2}{|c|}{ F2-D } & \multicolumn{2}{|c|}{ F2-E } & \multicolumn{2}{|c|}{$\begin{array}{c}\text { Proximal } \\
\text { (pum. and obs.) }\end{array}$} \\
\hline \multirow[t]{2}{*}{$n$} & \multicolumn{2}{|c|}{91} & \multicolumn{2}{|c|}{19} & \multicolumn{2}{|c|}{7} & \multicolumn{2}{|c|}{6} & \multicolumn{2}{|c|}{9} & \multicolumn{2}{|c|}{3} & \multicolumn{2}{|c|}{70} \\
\hline & Avg. & \pm & Avg. & \pm & Avg. & \pm & Avg. & \pm & Avg. & \pm & Avg. & \pm & Avg. & \pm \\
\hline $\mathrm{SiO}_{2}$ & 75.79 & 0.28 & 76.69 & 0.33 & 76.18 & 0.29 & 76.03 & 0.16 & 75.93 & 0.58 & 75.80 & 0.15 & 75.70 & 0.31 \\
\hline $\mathrm{TiO}_{2}$ & 0.10 & 0.03 & 0.10 & 0.04 & 0.11 & 0.02 & 0.09 & 0.01 & 0.11 & 0.02 & 0.13 & 0.02 & 0.14 & 0.03 \\
\hline $\mathrm{Al}_{2} \mathrm{O}_{3}$ & 14.14 & 0.26 & 13.58 & 0.26 & 13.79 & 0.25 & 13.99 & 0.18 & 14.09 & 0.5 & 14.00 & 0.13 & 14.02 & 0.22 \\
\hline $\mathrm{FeO}$ & 1.31 & 0.08 & 1.11 & 0.09 & 1.31 & 0.07 & 1.20 & 0.04 & 1.24 & 0.15 & 1.22 & 0.09 & 1.30 & 0.09 \\
\hline $\mathrm{MnO}$ & 0.07 & 0.04 & 0.06 & 0.02 & 0.05 & 0.04 & 0.06 & 0.05 & 0.05 & 0.03 & 0.08 & 0.05 & 0.06 & 0.04 \\
\hline $\mathrm{MgO}$ & 0.20 & 0.02 & 0.17 & 0.02 & 0.23 & 0.02 & 0.22 & 0.02 & 0.21 & 0.06 & 0.25 & 0.03 & 0.26 & 0.04 \\
\hline $\mathrm{CaO}$ & 1.25 & 0.05 & 0.96 & 0.08 & 1.24 & 0.04 & 1.27 & 0.03 & 1.22 & 0.08 & 1.35 & 0.07 & 1.36 & 0.07 \\
\hline $\mathrm{Na}_{2} \mathrm{O}$ & 4.04 & 0.11 & 3.87 & 0.10 & 3.92 & 0.11 & 3.94 & 0.17 & 3.91 & 0.20 & 3.94 & 0.23 & 3.95 & 0.13 \\
\hline $\mathrm{K}_{2} \mathrm{O}$ & 3.09 & 0.08 & 3.46 & 0.10 & 3.18 & 0.06 & 3.20 & 0.08 & 3.24 & 0.11 & 3.23 & 0.05 & 3.21 & 0.10 \\
\hline
\end{tabular}


collapse during a large explosive eruption; the lack of a thick fall deposit at this site may be explained by an upwind location, which is consistent with the eastward distribution of Mic2 (Fig. 1). Our calibrated date for Cha2 $(4.95 \pm 0.1 \mathrm{ka})$ is likely to be relatively accurate, since it is based on closely similar dates from large pieces of wood embedded in the deposit. The Naranjo and Stern (2004) calibrated date for Mic2 (4.2 $\pm 0.2 \mathrm{ka})$ is based on a single peat sample at the base of the distal fall deposit, which should also have provided a good radiocarbon sample. Acknowledging the discrepancy in radiocarbon age, Cha2 is nevertheless the best candidate in the F-02 sequence for correlation with the Mic2 tephra. We therefore suggest that $\mathrm{Cha} 2$ and Mic2 are equivalent deposits, rather than representing two separate large explosive eruptions from Chaitén.

The major-element chemistry of the proximal Chaitén 2008 samples overlaps with Cha1, Mic2 and the rhyolitic F-02 units (Cha2, Cha3 and Cha4) (Fig. 3). However, although the rhyolitic F-02 units occupy overlapping compositional fields, there are subtle but consistent compositional differences between them (Fig. 4), which exceed the instrumental $1 \sigma$ error. The major element compositions of pumice in Cha2 (F-02m) overlap closely with those
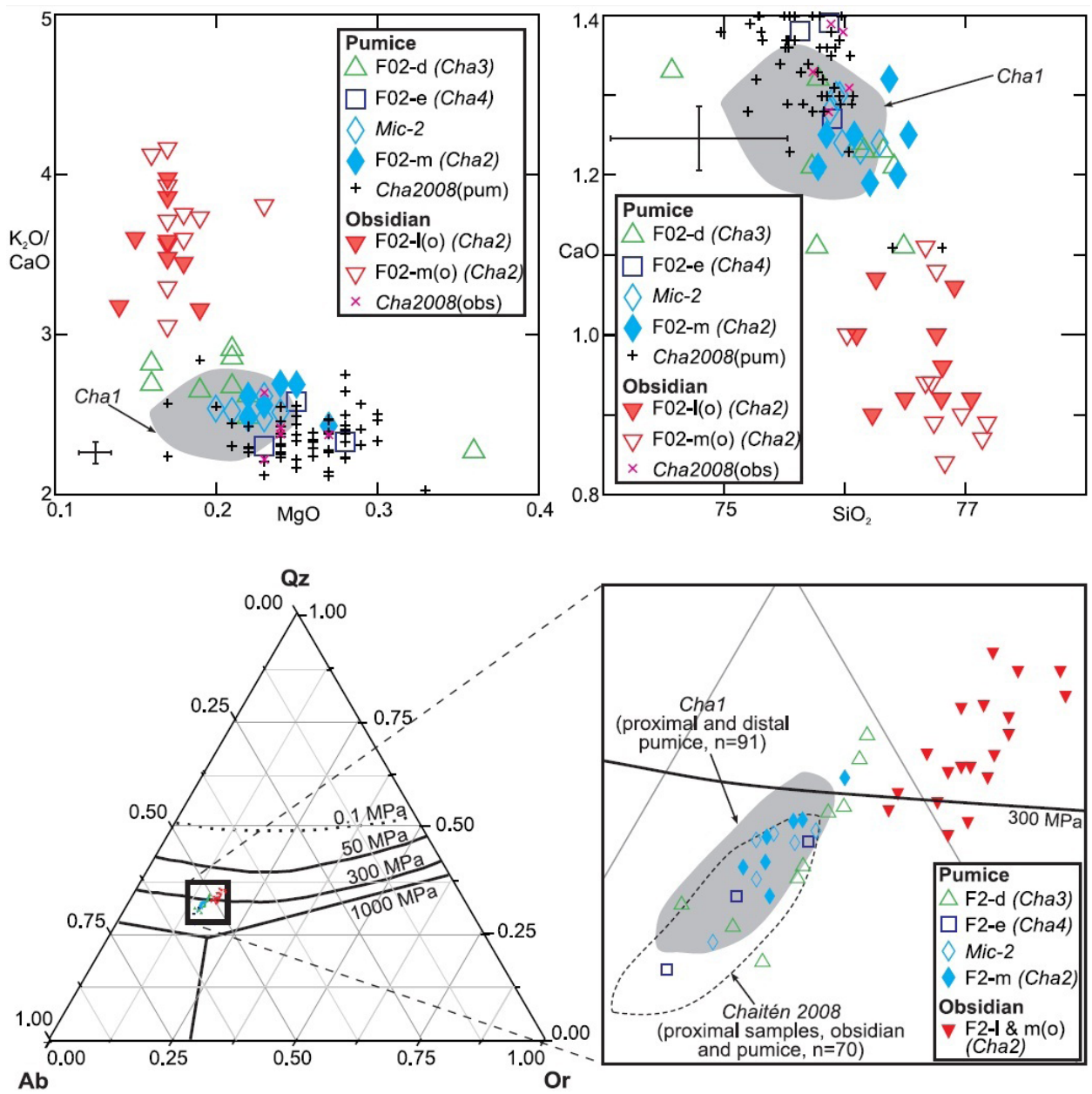

FIG. 4. Top: selected element plots for the Chaitén rhyolites (including Mic-2), discriminating between separate F-02 units. Obsidians from two sub-units of the Cha2 deposit (Fig. 2) have closely overlapping compositions, as do the Cha2 pumice (F-02m) and the Mic2 pumice. Representative $\pm 1 \sigma$ instrumental error bars are shown, based on the analytical variation of a rhyolitic secondary standard used to check instrument calibration. Bottom: granitic ternary diagram, plotted after Blundy and Cashman (2001) and showing water-saturated cotectic lines at selected pressures (the inset to the right shows detail of the plot). 
of Mic2, supporting our suggestion that the two units are equivalent. Pumices from $\mathrm{Cha} 3$ and Cha 4 (F-02d,e) have slightly more scattered compositions (but note the small ranges of the axes in figure 4) which suggest that the Cha3 glass is slightly poorer in $\mathrm{Mg}$ and richer in $\mathrm{K}$ than $\mathrm{Cha} 2$ and, based on very limited data, that the Cha4 glass is slightly richer in $\mathrm{Mg}$ and $\mathrm{Ca}$. These subtle differences in glass chemistry support our stratigraphic identification of three discrete rhyolitic units.

The obsidians sampled from both the basal debris-flow deposit and the overlying pumice-rich pyroclastic-flow deposit in Cha2 (Fig. 2) have identical glass major-element compositions (Fig. 4). This supports our conclusion that the Cha2 deposit represents a single eruptive episode. However, the obsidian glass within Cha2 is slightly richer in $\mathrm{K}$ and $\mathrm{Si}$ and poorer in $\mathrm{Ca}, \mathrm{Mg}$ and $\mathrm{Fe}$ than glass in pumices from Cha2 (Fig. 4). This compositional difference between pumice and obsidian from the same deposit contrasts with the Chaitén 2008 basal lapilli unit ( $\beta$-unit of Alfano et al., 2011), where pumice and obsidian grains have identical compositions (Fig. 4). The obsidian in Cha2 may therefore represent older material cleared from the vent or collapsed from an older lava dome, rather than juvenile lava. However, the Cha2 obsidians do not match the composition of the early Holocene Cha1 pumice (Fig. 4), and so may originate from a thus-far unidentified eruption occurring between Cha1 and Cha2.

The glass compositions presented here indicate equilibration of all of the Chaitén magmas at similar water-saturated conditions of $\sim 300 \mathrm{MPa}$, based on a plot of the compositional norms on a granitic ternary diagram (Fig. 4), following the method of Blundy and Cashman (2001). This plot updates an earlier version published in Watt et al. (2009). The compositional fields of Cha1 to Cha4, Chaitén 2008 and Mic2 all overlap. Their indicated equilibration pressure of $\sim 300 \mathrm{MPa}$ corresponds to pre-eruptive storage at depths of $\sim 10 \mathrm{~km}$. For the 2008 eruption, this is consistent with earthquakes recorded $\sim 10 \mathrm{~km}$ beneath Chaitén in 2005 (Lange et al., 2008), and also with the magma reservoir depth of 8-12 km modelled by Wicks et al. (2011). Petrological experiments (Castro and Dingwell, 2009) suggest slightly lower storage pressures for the 2008 magma, corresponding to depths of $5-7 \mathrm{~km}$. There are subtle differences between the defined compositional fields in figure 4: Mic2 and Cha2 (F2-m) are again very similar, supporting their correlation; Cha1 overlaps closely with Mic2/Cha2; Chaitén 2008 extends to slightly higher pressures and Cha3 to the lowest pressures. Again, the clearest outliers are the obsidians from Cha2, which define a consistently distinct compositional field from the pumices in the same deposit, in contrast to the similar compositions of pumice and obsidian in the Chaitén 2008 deposit. The Cha2 obsidians suggest lower equilibration pressures than any of the other Chaitén rhyolites analysed here, at $\sim 200 \mathrm{MPa}$, or a depth of $\sim 7 \mathrm{~km}$.

\section{Summary}

New data from a stratigraphic section (site F-02; base dated at $4.95 \pm 0.1 \mathrm{ka}) 2.5 \mathrm{~km} \mathrm{NW}$ of Chaitén Volcano show that Chaitén has erupted explosively on multiple occasions in the Holocene (Fig. 5). The earliest Holocene eruption at Chaitén, Cha1, occurred at $\sim 9.75 \mathrm{ka}$ (Watt et al., 2011a). This event is the second largest explosive eruption known from the volcano, exceeded only by the Cha2/Mic2 eruption. Since the stratigraphy at site F-02 only spans the mid- to late-Holocene (Fig. 5), we cannot directly assess evidence for further early Holocene explosive eruptions at Chaitén.

However, the presence of compositionally distinct obsidians within the Cha2 deposit, which neither match Cha1 nor juvenile Cha2/Mic2 compositions, suggest that post-Cha1 eruptions producing obsidian lavas may have occurred in the early Holocene.

The Cha 2 eruption occurred at $\sim 4.95 \mathrm{ka}$, and formed a sequence of pumice-rich pyroclastic density current deposits at site F-02, which we suggest lay in an upwind position. Based on the deposit's physical characteristics, composition and age, we correlate Cha2 with the Mic2 tephra fall deposit. The Mic2 deposit was identified in Argentina by Naranjo and Stern (2004), who suggested Michinmahuida Volcano as a possible source and dated the deposit at $\sim 4.2 \mathrm{ka}$ (Fig. 5). The Cha2/Mic2 eruption is the largest identified eruption from Chaitén, and one of the largest Holocene explosive eruptions in the SVZ, with a tephra volume of approximately $5 \mathrm{~km}^{3}$.

A weathered dacitic tephra lies a little above Cha2 in the F-02 sequence, and we suggest that this represents a hitherto unrecognised explosive eruption of Michinmahuida. Alternatively, it may correlate with the CM4 deposit (Heusser et al., 1992), probably from Yanteles Volcano. 


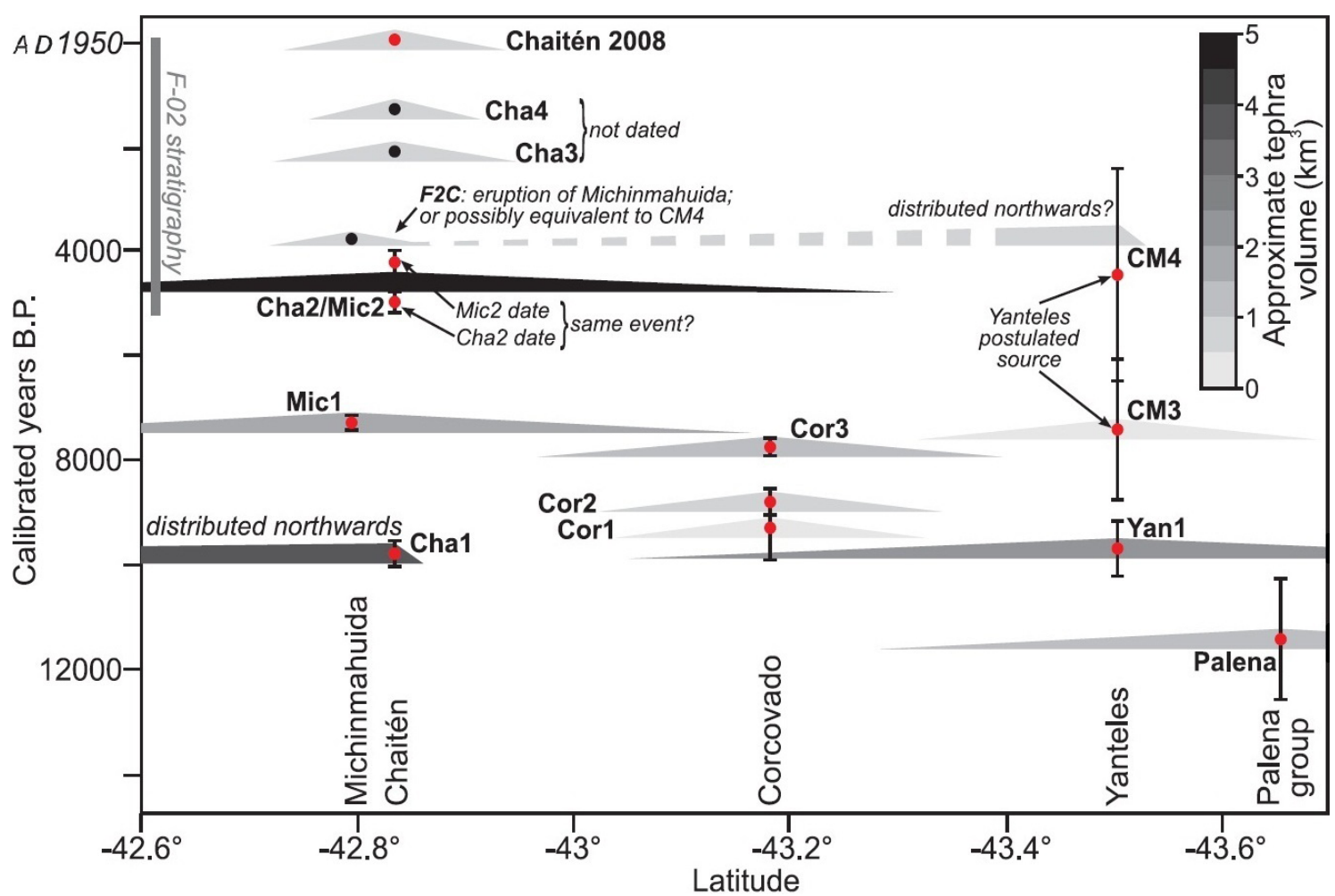

FIG. 5. Summary stratigraphy of tephra deposits from the segment of the SVZ around Chaitén. Calibrated eruption ages are shown with error bars. Tephra deposit extents are shown schematically as triangles (most are distributed eastwards and plotted as symmetrical cross sections), shaded according to approximate deposit volume. Data from Heusser et al., 1992; Naranjo and Stern, 2004; Watt et al., 2011a.

In the later Holocene, we identify two smallervolume rhyolitic tephra deposits (Cha3 and Cha4). The Chaitén 2008 eruption therefore becomes at least the fifth identified explosive eruption from Chaitén during the Holocene.

Far from having been quiescent for over 9000 years, Chaitén has in fact erupted explosively more frequently than its near neighbors (Michinmahuida, Corcovado, Yanteles, Huequi; Naranjo and Stern, 2004; Watt et al., 2011b). In the southern SVZ (south of Calbuco, $41.3^{\circ} \mathrm{S}$ ), a greater number of Holocene tephra deposits are recognised only from Hudson (45.9 ${ }^{\circ}$ S) (Naranjo and Stern, 1998, 2004; Watt et al., 2011a). Available regional tephra stratigraphies are, however, based on relatively limited field sampling. This work demonstrates that several moderately large explosive Holocene eruptions from this region could remain unrecognised. Eruption frequencies at several of the remote volcanoes of the southern SVZ may therefore be higher than is currently appreciated.
It is highly unusual for a volcano that has been active several times over a $10 \mathrm{kyr}$ period to have consistently erupted magma of virtually identical composition. As far as our data suggest, Chaitén has erupted rhyolitic magmas exclusively, producing homogeneous and crystal-poor pumice, obsidian or aphanitic lava (Castro and Dingwell, 2009; Watt et al., 2009). The consistent composition of Chaiten's magma stock is in sharp contrast to the diverse range of magmas erupted by neighboring centres (e.g., Naranjo and Stern, 2004). Indeed, rhyolites are rare to absent in other parts of the southern SVZ. The distinctive nature of Chaiten may reflect melting of a large body of the granitoid basement at this location. However, the process that uniquely produces rhyolitic volcanism at this site, which is not replicated elsewhere and occurs just $20 \mathrm{~km}$ on the trenchward side of a large, typical arc-frontal andesitic stratovolcano (Michinmahuida), remains unclear. 


\section{Acknowledgments}

This work was supported by NERC Urgency Grant NE/G001715/1. We are grateful to J. Major, Ch. Stern and Á. Amigo for detailed reviews and suggested improvements to the manuscript.

\section{References}

Alfano, F.; Bonadonna, C.; Volentik, A.C.M.; Connor, C.B.; Watt, S.F.L.; Pyle, D.M.; Connor, L.J. 2011. Tephra stratigraphy and eruptive volume of the May, 2008, Chaitén eruption, Chile. Bulletin of Volcanology 73: 613-630.

Blundy, J.; Cashman, K. 2001. Ascent-driven crystallisation of dacite magmas at Mount St Helens, 19801986. Contributions to Mineralogy and Petrology 140: 631-650.

Bronk Ramsey, C. 2009. Bayesian analysis of radiocarbon dates. Radiocarbon 51: 337-360.

Castro, J.M.; Dingwell, D.B. 2009. Rapid ascent of rhyolitic magma at Chaitén Volcano, Chile. Nature 461: 780-783.

Gudmundsson, A. 2009. Toughness and failure of volcanic edifices. Tectonophysics 471: 27-35.

Haberle, S.G.; Lumley, S.H. 1998. Age and origin of tephras recorded in postglacial lake sediments to the west of the southern Andes, $44^{\circ} \mathrm{S}$ to $47^{\circ} \mathrm{S}$. Journal of Volcanology and Geothermal Research 84: 239-256.

Heusser, C.J.; Heusser, L.E.; Hauser, A. 1992. Paleoecology of late Quaternary deposits in Chiloé continental, Chile. Revista Chilena de Historia Natural 65: 235-245.

Kilian, R.; López-Escobar, L. 1991. Petrology of the Southern Southandean Volcanic Zone $\left(41^{\circ}-46^{\circ} \mathrm{S}\right)$ with emphasis on the Michinmáhuida-Chaitén complex. Zentralblatt für Geologie und Paläontologie 1: 1693-1708.

Lange, D.; Cembrano, J.; Rietbrock, A.; Haberland, C.; Dahm, T.; Bataille, K. 2008 First seismic record for intra-arc strike-slip tectonics along the Liquiñe-Ofqui fault zone at the obliquely convergent plate margin of the southern Andes. Tectonophysics 455: 14-24.

Lara, L.E. 2009. The 2008 eruption of the Chaitén Volcano, Chile: a preliminary report. Andean Geology 36 (1): 125-129.

López-Escobar, L.; Kilian, R.; Kempton, P.; Tagiri, M. 1993. Petrography and geochemistry of Quaternary rocks from the Southern Volcanic Zone of the Andes between $41^{\circ} 30^{\prime}$ and $46^{\circ} 00^{\prime} \mathrm{S}$, Chile. Revista geológica de Chile 20 (1): 33-55.
McCormac, F.; Hogg, A.; Blackwell, P.; Buck, C.; Higham,T.; Reimer, P. 2004. SHCal04 Southern Hemisphere calibration, 0-11 cal. kyr BP. Radiocarbon 46: 1087-1092.

Naranjo, J.A.; Stern, C.R. 1998. Holocene explosive activity of Hudson Volcano, southern Andes. Bulletin of Volcanology 59, 2: 291-306.

Naranjo, J.A.; Stern, C.R. 2004. Holocene tephrochronology of the southernmost part $\left(42^{\circ} 30^{\prime}-45^{\circ} \mathrm{S}\right)$ of the Andean Southern Volcanic Zone. Revista Geológica de Chile 31 (2): 224-240.

Pallister, J.S.; Diefenbach, A.; Burton W.; Muñoz J.; Griswold J.; Lara L.; Lenstern J.; Valenzuela C. 2013. The Chaitén rhyolite lava dome: Eruption sequence, lava dome volumes, rapid effusion rates and source of the rhyolite magma. Andean Geology 40 (2): 277-294.

Pyle, D.M. 1989. The thickness, volume and grainsize of tephra fall deposits. Bulletin of Volcanology 51: 1-15

Pyle, D.M. 1999. Widely dispersed Quaternary tephra in Africa. Global and Planetary Change 21: 95-112.

Stern, C.R. 2004. Active Andean volcanism: its geologic and tectonic setting. Revista Geológica de Chile 31(2): 161-206.

Stewart, C.; Pizzolon, L.; Wilson, T.; Leonard, G.; Dewar,D.; Johnston, D.; Cronin, S. 2009. Can volcanic ash poison water supplies? Integrated Environmental Assessment and Management 5: 713-716.

Wang, K.Y.; Lin, S.C.; Lee, L.C. 2009. Immediate impact of the Mt Chaitén eruption on atmosphere from FORMOSAT-3/COSMIC constellation. Geophysical Research Letters 36 (L03808). doi: 10.1029/2008GL036802

Watt, S.F.L.; Pyle, D.M.; Mather, T.A.; Martin, R.S.; Matthews, N.E. 2009. Fallout and distribution of volcanic ash over Argentina following the May 2008 explosive eruption of Chaitén, Chile. Journal of Geophysical Research 114 (B04207). doi: 10.1029/2008JB006219.

Watt, S.F.L.; Pyle, D.M.; Naranjo, J.A.; Rosqvist, G.; Mella, M.; Mather, T.A.; Moreno, H. 2011a. Holocene tephrochronology of the Hualaihue region (Andean southern volcanic zone, $\sim 42^{\circ} \mathrm{S}$ ), southern Chile. Quaternary International 246: 324-343.

Watt, S.F.L.; Pyle, D.M.; Mather, T.A. 2011b. Geology, petrology and geochemistry of the dome complex of Huequi Volcano, southern Chile. Andean Geology 38 (2): 335-348.

Wicks, C.; de la Llera, J.C.; Lara, L.E.; Lowenstern, J. 2011. The role of dyking and fault control in the rapid onset of eruption at Chaitén Volcano, Chile. Nature 478: 374-377. 